\title{
Childhood Focal Osteomyelitis in A Developing Community
}

\author{
Wilson I. B. Onuigbo ${ }^{1 *}$ and Samuel O. C. Emedike ${ }^{2}$ \\ ${ }^{1}$ Department of Pathology, University Teaching Hospital, Enugu \\ ${ }^{2}$ Department of Surgery, University Teaching Hospital, Abakaliki
}

Submission: March 16, 2017; Published: March 24, 2017

*Corresponding author: Wilson I. B. Onuigbo, Department of Pathology, University Teaching Hospital, Enugu, Nigeria,

Email: wilson.onuigbo@gmail.com

\begin{abstract}
In 1980, osteomyelitis in childhood was presented from mostly the Yorubas of the Western part of Nigeria with reference to salmonella infection. Of interest, there were the findings of its being most prevalent in the first 2 years of life, and of the 2:1 male to female ratio. Therefore, the present study concerns Igbo elements of the Eastern part but without laboratory identification. The ratio was the same but the first 5 years proved to be the least involved. The findings are discussed at some length including the scarcity of spinal cases.
\end{abstract}

Keywords: Osteomyelitis; Bone Selection; Sex Ratio, Age; Igbos; Nigeria

\section{Introduction}

The interest in the reprint request (RR) led the senior author (WIBO), who was classified by the Editor of English for Specific Purposes as the world's leader in RR research [1], to obtain an interesting RR from the Western Region of Nigeria in 1980 [2]. It dealt specifically with salmonella infestation and showed maximum occurrence in the first 2 years of life as well as a male:female ratio of $2: 1$. Therefore, the present paper dealt on the Ibos of the Eastern part of Nigeria although there was no determination of the bacteriological causes.

\section{Patients}

All the 33 patients were Nigerian children of the Igbo ethnic group [3]. The specimens were received at the Regional Pathology Laboratory for the most part. Table 1 shows their age and sex distribution. As focal sites were studied individually, Table 2 shows the predominance of the lower extremity, especially the tibia and femur. Single sites were only those of the spine, mandible and malleolus.

Table 1: Age/sex distribution pattern.

\begin{tabular}{|c|c|c|c|}
\hline Age & M & F & Total \\
\hline $0-5$ & 3 & 2 & 5 \\
\hline $6-10$ & 6 & 5 & 11 \\
\hline $11-15$ & 13 & 4 & 17 \\
\hline Total & 22 & 11 & 33 \\
\hline
\end{tabular}

Table 2: Distribution by bone involvement.

\begin{tabular}{|c|c|}
\hline Bone & Number \\
\hline Tibia & 9 \\
\hline Femur & 7 \\
\hline Humerus & 4 \\
\hline Ulna & 3 \\
\hline Rib & 3 \\
\hline Fibula & 2 \\
\hline Scapula & 2 \\
\hline Spine & 1 \\
\hline Mandible & 1 \\
\hline Malleolus & 33 \\
\hline Total & \\
\hline
\end{tabular}

\section{Discussion}

It is considered that acute osteomyelitis in children is considerably more common in low-income countries [4]. A major area of interest is in cure [5-7]. However, it is not applicable here, seeing that their specimens were seen and not the individual patients. 
It is of interest that spinal osteomyelitis is so common in New Zealand as to deserve the review of 61 cases [8]. In contrast, only one case was encountered in the present series.

The role of X-Ray in management is noteworthy [6]. Therefore, it suffices to mention that 15 clinicians thought it fit to include their use of it in the present cohort. In this context, it should be mentioned that this paper is in line with the recommendation of Birmingham (UK) group [9], that the establishment of a histopathology data pool improves epidemiological analysis. Such a pool has been used here.

Incidentally, unlike other authors [10-12], this presentation does not include multiple-site osteomyelitis. It deserves future consideration elsewhere.

\section{References}

1. Swales J (1986) ESP in the big world of reprint requests. English Specific Purposes 5(1): 81-85.

2. Adeyokunnu AA, Hendrickse RG (1980) Salmonella osteomyelitis in childhood. Arch Dis Childhood 55: 175-184.

3. Basden GT (1966) Niger Ibos. Cass, London, UK.
4. Peltola H, Paakkonen M (2014) Acute osteomyelitis in children. N Engl J Med 370: 352-360.

5. Cole WG, Dalziel RE, Leitl S (1982) Treatment of acute osteomyelitis in childhood. J Bone Joint Surg 64(2): 218-223.

6. van Schuppen J, van Doorn MMAC, van Rijn RR (2012) Childhood osteomyelitis: imaging characteristics. Insights Imaging 3(5): 519-533.

7. Harik NS, Smeltzer MS (2010) Management of acute hematogenous osteomyelitis in children. Expert Rev Anti Infect Ther 8(2): 175-181.

8. Silverthorn KG, Gillespie WJ (1986) Pyogenic spinal osteomyelitis: a review of 61 cases. N Z Med J 99(795): 62-65.

9. Macartney JC, Rollaston TP, Codling BW (1980) Use of a histopathology data pool for epidemiological analysis. J Clin Pathol 33(4): 351-353.

10. Diard F, Kozlowski K, Masel J, Marc J (1983) Multifocal, chronic, nonstaphylococcal osteomyelitis in children (Report of four cases aspergillosis, klebsiella, tuberculosis. Australas Radiol 27(1): 39-44.

11. Kozlowski K, Masel J, Harbison S, Yu J (1983) Multifocal chronic osteomyelitis of unknown etiology. Pediatr Radiol 13(3): 130-136.

12. Kozlowski K, Beluffi G, Feltham C (1985) Multifocal, chronic osteomyelitis of unknown etiology. Fortschr Rontgenstr 142(4): 440446.

\section{Your next submission with Juniper Publishers} will reach you the below assets

- Quality Editorial service

- Swift Peer Review

- Reprints availability

- E-prints Service

- Manuscript Podcast for convenient understanding

- Global attainment for your research

- Manuscript accessibility in different formats

( Pdf, E-pub, Full Text, Audio)

- Unceasing customer service

Track the below URL for one-step submission https://juniperpublishers.com/online-submission.php 